For citation: Ekonomika regiona [Economy of Region]. - 2016. — Vol. 12, Issue 4. - pp. 1050-1059

doi 10.17059/2016-4-7

UDK $330+327.33$

E. L. Andreeva ${ }^{\text {a, b) }}$, A. F. Linetsky a,b), A. V. Ratner ${ }^{\text {a) }}$, D. E. Kuznetsova ${ }^{\text {a) }}$

a) Institute of Economics of the Ural Branch of RAS (Ekaterinburg, Russian Federation; e-mail: elenandr@mail.ru)

b) Ural State University of Economics (Ekaterinburg, Russian Federation)

\title{
INSTITUTIONAL FACTOR IN INTERNATIONAL ECONOMIC ACTIVITY OF REGION AND ITS SOCIO-ECONOMIC DEVELOPMENT ${ }^{1}$
}

The article substantiates the impact of the institutional factor on the development of regional international economic relations. The scope of the study is regional international economic activity (IEA), the subject-matter is the role of the institutional factor in its development. The study purpose is to develop a scientific approach for the assessment of the institutional factor impact on the development of region's international economic relations. The hypothesis is that the targeted efforts of all participants of IEA of the region (business, authorities, local community) to strengthen of theese components of the institutional factor, which have a strong influence on the regional socio-economic development. A methodological approach for the assessment of this influenceis developed. It includes determining three elements of IEA institutionalization-agreements, organizations, events. A three-dimensional model is proposed for the coordination of these elements with 3 groups of countries - developed, developing and CIS, including the Eurasian Economic Union, and also with basic indexes characterizing the qualitative and quantitative contribution of region's IEA into its socio-economic development. This model is tested on the example of the Sverdlovsk region of Russia for 2003-2015. That has allowed to define various kinds of the effects from strenthening the IEA institutional component, which are expressed in the increase of the export of the region, improvement of its investment attractiveness, the diversification of regional economy as well as the the generation of additional jobs and tax flows increase.

Keywords: institutional factor, international economic activity, international trade, international economic agreements, regional economic development, international measurements, international economic associations, efficient international economic contacts, international trade structure, qualitative and quantitative effect

\section{Introduction}

For the purposes of discussion, the international economic activity (IEA) of a country and a region can be divided into a process component, i.e., the processes of international movement of goods and production factors, and an institutional component, i.e., institutions supporting these processes. Processes of international movement of goods and production factors include movements between the national economies of goods (in the broad sense of the word, i.e., including material goods and services), i.e., international trade, and production factors - capital (international investments), workforce (external labor migration) and technology (international technology trade).

The role of institutes in the development of the regional economy is investigated in detail; in particular, it has found reflection in the works of E.V. Popov [1], V.M. Polterovich [2], D. Nort [3], etc. Such authors as J. Francois, [4], K. He [5], J. Kucik [6] study the institutions of international economic integration, the institutional framework

${ }^{1}$ (c) Andreeva E. L., Linetskiy A. F., Ratner A. V., Kuznetsova D. E. Text. 2016. of such kinds of international interaction, as trade and technological.

Of course, a number of factors influence on the development of the region as a whole and its international activity, in particular. A wide range of indicators of regional socio-economic development is used, including the level of its innovative and scientific-technological development [7, 8] as well as corporate social responsibility [9]. It is necessary the consideration of the ratio of international economic and interregional relations of the region (L.M. Kapustina) [10], economic safety (A.A. Kuklin) [11], etc. (for example, [12]). The factors of region's export potential are allocated (M.I. Maslennikov) [13]. The special attention is paid to the analysis of the production of the international economic potential of intra-country regions (A.A. Maltsev), geo-economic positioning of territories [14] and a role of fair and exhibition activity for the international economic positioning of the region [15] (E.D. Frolova), development of trade and economic cooperation of Russian region with the CIS countries (A.A. Maltsev, A.F. Linetsky) [16]. A number of researchers consider the innovative factor as the most impor- 
tant factor of regional international economic potential development, in particular, a role of special economic zones (A.O. Sobolev) [17]. On the whole, the resource, functional, competitive, "income" and progress approaches are highlighted by researchers to the understanding of export potential. At that, the production, marketing, financial and labor factors of export potential are considered with revealing the correlation relationship [18]. Since the 1990s, the significant attention has been paid to the factor of national currency's exchange rate. The relationship of its dynamics with international trade dynamics was investigated also by the means of correlation-regression analysis.

We offer to mark two components of IEA - the process and the institutional ones [19]. The second component, however, has not found a detailed reflection as an independent factor. It has predetermined a need for the development of methodological approach to the assessment of the impact of an institutional factor in IEA of the region on its socio-economic development.

\section{Institutional component of IEA on the country's region level}

A country's region, just like the country as a whole, is involved in all the areas of IEA. A region is a part of the country, and therefore:

- it is subordinated to the federal center and, consequently, its legal capacity is much lower than that of the country, and has a different nature;

- it has a certain geographical position with relation to foreign countries and other regions of the country;

- it is described by both international economic relations and economic links with other regions of the country (i.e., it is a part of the country's economic complex).

Consequently, a country's region will have its own specifics of IEA institutional component (however, all institutional standards are set by the federal center) that will be expressed by making the international cooperation agreements with the regions of foreign countries. Both native [10, $20,21]$ and foreign $[22,23]$ researchers underline a high role of international economic agreements. But they are studied as a rule on the state level.

Note that the sub-sphere of trade may include an arrangement of trade fairs and exchange of delegations, assistance in establishing trade companies, assistance in developing leasing projects and provisions for the legal protection of other party's economic agents. The cooperation's interaction provides the establishment of joint ventures, the creation of conditions for the mutual supplies of goods for production and technical needs. In the area of international investments, conditions can be created for attracting mutual investments into the parties' economies, also for the functioning of the companies with another party's investments. The economic information exchange assumes mutual information sharing about the parties' economic policies, market condition, needs for raw materials, components, finished product. There are plans for the exchange of experience in the field of creating new jobs, etc. The agreements also suggest a variety of institutional frameworks: an appointment of cooperation bodies, the establishment of joint boards, the opening of representative offices, regional information centers, etc.

At the same time, it should be noted that the impact assessment of institutional foreign economic activity on the economy of the region requires the detailing in the methodological plan.

\section{Research methodology of the influence of IEA institutional factor on the development of regional economy}

Within the development of methodological approach, we offer to allocate three components of the institutionalization of region's IEA:

- agreements of the region about economic cooperation in various spheres with authorities of foreign countries' regions;

- institutionalization of the international economic partnership of countries in the form of associations, which will be manifested also at the level of regions of member countries;

- organizing and carrying out in the region international events relating to international cooperation in various economic branches (summits, exhibitions and fairs, visits of delegations), with the use of new network technologies of interaction.

It is offered to consider these components by the following three groups of the countries - international economic partners of Russia:

- developed countries (EU, NAFTA, ASEAN countries, etc.) with which Russian regions traditionally had the greatest IEA share;

- developing countries - partners - first of all, after SCO, BRICS group; also the countries with which Russia developed economic cooperation in Soviet period (Vietnam, Mongolia); and also the countries of Latin America whose role increases in current geo-economic terms;

- partner countries by means of CIS, including Eurasian Economic Union (EAEU), which represents a perspective integration association.

At that, the influence of three manifestations of institutional factor in IEA with various coun- 


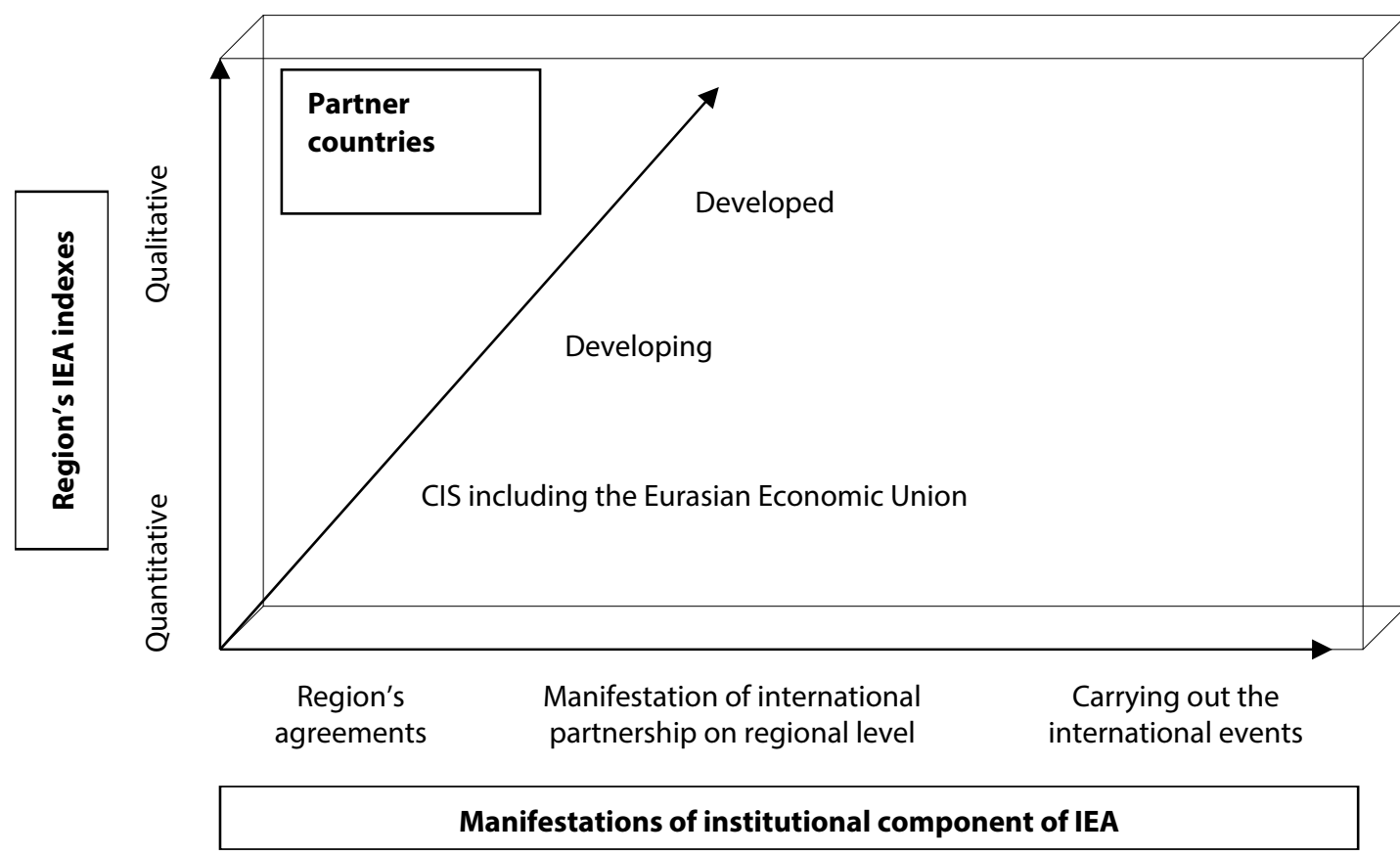

Fig. 1. Methodology of the research of the influence of an institutional factor of region's IEA (international economic activity) on its socio-economic development

tries' groups on regional economic development can be expressed in quantitative and qualitative indices:

- quantitative indices include a change (increase) of region's export volume, creation of workplaces, increase of the share of innovative production in general production structure, increase of tax revenue, of investments inflow, etc.;

- qualitatively, the influence of institutional factor can be expressed as the improvement of the image of the region, diversification of its economy, technological development, etc.

The research of institutional factor influence on the development of regional economy according to the offered methodology allows to propose subsequently a complex of recommendations for the optimization of region's IEA.

Thus, the offered methodology assumes the use of data according to three vectors. As the result, it gives the three-dimensional model of 18 elements: 3 manifestations of IEA institutional component; 3 groups of countries; 2 blocks of indicators (quantitative and qualitative) (figure 1).

The calculation of the complete effect of an institutional factor for the economic development of a chosen region requires the availability of wide statistical base and can be a subject of separate research. In our case, we have carried out the testing of the methodology offered in the example of the Sverdlovsk region of Russia by the separately selected elements planed by the methodology of three-dimensional database.

\section{The assessment of institutional factor influence on the economic development of Sverdlovsk region}

1. Regarding economic cooperation agreements with regions of Russia's partner countries, the Sverdlovsk region is an active region: it is made 36 agreements acting at the moment - with authorities of two tens of countries (more often, with authorities of regional level). At that time, $58 \%$ of agreements are signed with the CIS countries (Belarus, Kazakhstan, Armenia, Azerbaijan, Kyrgyzstan, Uzbekistan, Tajikistan, etc.), 19,5\%-with other developing countries (China, Vietnam), $22 \%$-with developed countries (mostly - with the partner countries of the former USSR) (according to the website of the Ministry of International and Foreign Economic Relations of Sverdlovsk region (Retrieved from: http://mvs.midural.ru/soglasheniya). In general, the agreements assume measures in following spheres:

- in the sphere of trade (in particular, assistance in the establishing of contacts between enterprises and trade contracts);

- in the sphere of investments (in particular, creating the favorable conditions for the attraction of investments into the economy of parties);

- in the sphere of a labor migration (in particular, the creation of workplaces intended for external migrants as well);

- in the sphere of the movement of technologies (in particular, assistance in the organizing the joint high technology productions); 
Table 1

Intensity of international contacts as comparison to the dynamics of volumes of international economic activity of Sverdlovsk region, 2003-2015

\begin{tabular}{|c|c|c|c|c|c|c|c|c|c|c|c|c|c|}
\hline & 2003 & 2004 & 2005 & 2006 & 2007 & 2008 & 2009 & 2010 & 2011 & 2012 & 2013 & 2014 & $\begin{array}{c}2015 \\
(11 \\
\text { months }) \\
\end{array}$ \\
\hline \multicolumn{14}{|c|}{ Movement of delegations between the region and foreign countries } \\
\hline Total number of receptions & 48 & 46 & 49 & 29 & 33 & 51 & 92 & 53 & 39 & 61 & 85 & 75 & 125 \\
\hline $\begin{array}{l}\text { 1. Reception in Sverdlovsk } \\
\text { Region of Ambassadors } \\
\text { Extraordinary and } \\
\text { Plenipotentiary of foreign } \\
\text { countries to the Russian } \\
\text { Federation }\end{array}$ & 8 & 10 & 12 & 9 & 11 & 15 & 25 & 21 & 18 & 13 & 22 & 22 & 50 \\
\hline $\begin{array}{l}\text { 2. Reception in Sverdlovsk } \\
\text { Region of foreign govern- } \\
\text { ment delegations }\end{array}$ & 4 & 4 & 9 & 6 & 5 & 11 & 37 & 11 & 8 & 6 & 18 & 23 & 40 \\
\hline $\begin{array}{l}\text { 3. Reception in Sverdlovsk } \\
\text { Region of any other official } \\
\text { foreign delegations }\end{array}$ & 36 & 32 & 28 & 14 & 17 & 25 & 30 & 21 & 13 & 42 & 45 & 22 & 35 \\
\hline Total number of visits & 20 & 23 & 24 & 18 & 30 & 33 & 19 & 22 & 40 & 47 & 28 & 18 & 16 \\
\hline $\begin{array}{l}\text { 1. Visits abroad of the del- } \\
\text { egations of Sverdlovsk } \\
\text { Region headed by the } \\
\text { Governor of Sverdlovsk } \\
\text { Region }\end{array}$ & 5 & 13 & 5 & 8 & 7 & 10 & 6 & 11 & 10 & 3 & 4 & 5 & 4 \\
\hline $\begin{array}{l}\text { 2. Other visits abroad of the } \\
\text { officials and delegations of } \\
\text { Sverdlovsk Region }\end{array}$ & 16 & 10 & 19 & 10 & 23 & 23 & 13 & 11 & 30 & 44 & 24 & 13 & 12 \\
\hline $\begin{array}{l}\text { Total number of receptions } \\
\text { and visits }\end{array}$ & 68 & 69 & 73 & 47 & 63 & 84 & 111 & 75 & 79 & 108 & 113 & 93 & 141 \\
\hline \multicolumn{14}{|c|}{ International economic activity } \\
\hline $\begin{array}{l}\text { Foreign trade turnover, } \\
\text { USD billion }\end{array}$ & 4.3 & 6.2 & 7.4 & 8.9 & 12.1 & 14.6 & 9.9 & 12.3 & 12.2 & 13.0 & 11.1 & 11.8 & - \\
\hline Export, USD billion & 3.3 & 4.9 & 5.9 & 7.1 & 9.3 & 10.3 & 7.3 & 8.9 & 8.5 & 9.6 & 7.8 & 8.2 & - \\
\hline Import, USD billion & 1.0 & 1.3 & 1.5 & 1.8 & 2.8 & 4.3 & 2.6 & 3.4 & 3.7 & 3.4 & 3.3 & 3.6 & - \\
\hline $\begin{array}{l}\text { Inflow of international in- } \\
\text { vestments, USD million }\end{array}$ & 1318 & 517 & 1094 & 1390 & 1338 & 2114 & 1367 & 1522 & 1568 & 5204 & 1574 & - & - \\
\hline $\begin{array}{l}\text { Share of machine-technical } \\
\text { products in export, } \%\end{array}$ & 15.1 & 9.6 & 6.2 & 9.5 & 11.1 & 10.5 & 16.2 & 17.7 & 10.5 & 18.4 & 15.0 & 15.1 & - \\
\hline
\end{tabular}

It is prepared on the basis of the data of the official web-site of the Ministry of International and Foreign Economic Relations of Sverdlovsk region (Retrieved from: www.mvs.midural.ru; (date of access: 30.11.2015) and of Territorial Branch of Federal State Statistics Service of Sverdlovsk region.

- in tourism (encouragement to provide privileges to the tourists of other countries);

- in transport transit (equipping the infrastructure, providing the camping, etc.);

- in industrial cooperation (rendering the juridical support to joint enterprises);

- in general, in the sphere of further institutional provision of economic partnership (appointment of authorized bodies and organizing the working groups coordinating the implementation of all measures);

- in exchange and cooperation in science and education (assistance to organizing the joint seminars and scientific projects).
All these measures promote economy's revival, create new workplaces, give a contribution to a growth of the gross regional product. Besides, they give qualitative effect by promoting the export diversification, growth of a share of finished goods including high-technological. As a quantitative index, the growth of international trade and international investments was taken, and as a qualitative - the share of machine-technical products in export. The correlation-regression analysis of the dependence of the development of international contacts and these indicators was carried out (Table 1). 
Table 2

Correlation coefficients between the intensity of international contacts and the international economic development of Sverdlovsk region, 2003-2014

\begin{tabular}{|l|c|c|c|}
\hline \multirow{2}{*}{$\begin{array}{c}\text { Data of the region's international economic } \\
\text { development }\end{array}$} & $\begin{array}{c}\text { Total number } \\
\text { of receptions }\end{array}$ & $\begin{array}{c}\text { Total number } \\
\text { of visits }\end{array}$ & $\begin{array}{c}\text { Total number } \\
\text { of receptions and visits }\end{array}$ \\
\cline { 2 - 4 } & 0.15 & $0.55^{* 1)}$ & 0.38 \\
\hline International trade turnover & 0.07 & $0.55^{* 2}$ & 0.31 \\
\hline Export & 0.28 & $0.51^{* 3)}$ & $0.50^{* 4)}$ \\
\hline Import & -0.13 & 0.49 & 0.09 \\
\hline International trade balance & 0.16 & $0.76^{* 5)}$ & 0.48 \\
\hline Inflow of international investments (2003-2013) & $0.62^{* 6)}$ & 0.15 & $0.67^{* 7)}$ \\
\hline $\begin{array}{l}\text { Share of machine-technical products in export } \\
(2004-2014)\end{array}$ & & & \\
\hline
\end{tabular}

Source: calculated on the basis of table 1 .

The cases of middle or high extent of correlation relationship are allocated.

Note. Correlation relationship reflecting the highlighted correlation coefficients are expressed by means of the following equations:

$\left.{ }^{\left.{ }^{*} 1\right)} Y=0.181 x+5.458,{ }^{\left.{ }^{*} 2\right)} Y=0.122 x+4.331,{ }^{\left.{ }^{*} 3\right)} Y=0.060 x+1.127,{ }^{* 4)} Y=0.026 x+0.604,{ }^{{ }^{*} 5}\right) Y=99.5 x-1022,{ }^{* 6)} Y=0.118 x+6.157$,

${ }^{* 7)} Y=0.124 x+2.395$.

Table 3

The share of Azerbaijan in the structure of export of the chosen goods of Sverdlovsk region, \%, 2009-2014

\begin{tabular}{|c|c|c|c|c|c|}
\hline & 2009 & 2011 & 2012 & 2013 & 2014 \\
\hline Forest products & 45,7 & 45,9 & 48,2 & 55,9 & 49,9 \\
\hline Iron or steel rods & 0,1 & 0 & 0 & 9,7 & 14,1 \\
\hline $\begin{array}{l}\text { Pipes, tubes and hollow profiles from ferrous metals (except an iron } \\
\text { casting) }\end{array}$ & 4,7 & 4,0 & 7,1 & 11,3 & 7,7 \\
\hline Engines and electric generators & 0,2 & 0 & 2,2 & 0,4 & 39,7 \\
\hline Isolated wires & 0 & 0,5 & 2,6 & 1,2 & 33,9 \\
\hline Parts and accessories of motor vehicles & 0,3 & 32,4 & 36,2 & 30,4 & 30,1 \\
\hline
\end{tabular}

International trade of Sverdlovsk region for 2009-2014: statistical bulletins. Territorial branch of Federal State Statistics Service of Sverdlovsk region. Yekaterinburg, 2010-2015.

The amount of ambassadors of foreign states (50), the amount of foreign - governmental as well as the official delegations visited Sverdlovsk region in 2015 was record-breaking for the last 13 years. Foreign delegations arrived in Yekaterinburg to take part in the industrial exhibition "Innoprom", $\mathrm{X}$ International Exhibition of Arms, Military Equipment and Ammunition of "RussiaArms EXPO 2015”, VII Russian-German Forum of Energy Efficiency, VI Russian-Azerbaijani Forum, and other events.

Table 1 demonstrates that annually, the total of the receptions of foreign delegations in many times exceeds the number of the visits of Sverdlovsk region delegations abroad (in 2015 the number of receptions -125 , the number of visits -16). It means that Sverdlovsk region is interested to foreign partners.

So, the international contacts have grown steadily during the whole period except the crisis of 2010 and 2014 years. Also, during the whole period, the growth of the international trade turnover of Sverdlovsk region was stable. At that, if the number of the international contacts in 2014 in comparison with 2003 has increased approximately by 1.4 times, the volume of the international trade turnover for this period has grown by 2.7 times. It shows that there can be a correlation between the indexes of international contacts and the indexes of international trade. Correlation analysis is shown in table 2.

Thus, for the region, the middle or even high extent of correlation of IEA indexes with the total number of delegations' movement is revealed. By other indexes, the dependency is weak (table 2). On the one hand, it indicates the influence of institutional factor on regional international economic development. On the other hand, it points to the influence of other factors that has already been mentioned above. A big role is played by the exchange rate of ruble relating to the currencies of partner countries.

The efficiency of international contacts can be illustrated by two examples of the relations between the Sverdlovsk region and the CIS countries (including EAEU). It is caused by the fact that in terms of international economic restrictions from developed countries, communication with devel- 
Table 4

The changes in the export of machine-technical production of Sverdlovsk region to Azerbaijan, expressed in physical terms

\begin{tabular}{|l|c|c|c|c|c|}
\hline \multicolumn{1}{|c|}{ Products } & $\mathbf{2 0 0 9}$ & $\mathbf{2 0 1 1}$ & $\mathbf{2 0 1 2}$ & $\mathbf{2 0 1 3}$ & $\mathbf{2 0 1 4}$ \\
\hline $\begin{array}{l}\text { Engines and electric } \\
\text { generators, items }\end{array}$ & 2 & 0 & 29 & 2 & 135 \\
\hline Isolated wires, tons & 0 & 1 & 6 & 6 & 38 \\
\hline $\begin{array}{l}\text { Parts and accessories of } \\
\text { motor vehicles, tons }\end{array}$ & 1 & 110 & 124 & 98 & 86 \\
\hline
\end{tabular}

International trade of Sverdlovsk region for 2009-2014.

oping countries, and with the CIS countries, in particular, became more active. Azerbaijan acts as the first example, as it has moved from 24th to the 5 th place in the regional international trade turnover. The trade with is characterized by the most positive structural change for the region (tab. 3, 4). Regarding the agreements with the regional and other administrative structures of the CIS countries (out of EAEU), it is possible to give an example of such country-Russia's partner by the CIS, as Azerbaijan. The agreement of the Government of the Sverdlovsk region of the Russian Federation with the Azerbaijan Republic's Government about trade, economic, scientific and technical cooperation was made in February 2006. It is characteristic that the trade turnover of the region with this country for the next years has considerably grown. As for the last years: 2010 it constituted 96 USD million, 2011-131, 2012-126, 2013-274, 2014-643 USD million (to the Ural customs administration).

Of course, the development of the institutional provision of relations served as not the only factor of the changing of the structure and dynamics of Sverdlovsk region's export to Azerbaijan. The big role, as it has been already mentioned, was played also by such index as a currency exchange rate: if in 2009, 1 Azerbaijani manat cost 37.5 to $44.1 \mathrm{ru}-$ bles, $2014-41,7$ to 86,5 rubles (to the data of the web-site of Central bank of Russia). The depreciating Russian ruble caused by global financial and economic crisis significantly raised the competitiveness for Russian export of machines and equipment. However, the ruble was depreciated relating many other currencies too. Although, the jump upwards in a mutual trade by the Sverdlovsk region was happened only with some countries, including Azerbaijan, in which there was the raised of the export of machinery products.

In general, as a result of the visit of Sverdlovsk delegation in 2014 to Azerbaijan, the large industrial projects have been started. They are the building of the production of upsetting pipes plant for the needs of the Azerbaijani oil indus- try (the participants of the project are JSC Pipe Metallurgical Co., the LC "The Azerbaijani complex of steel production"). Direct cooperation between the ministry of Defense of the Republic of Azerbaijan and JSC Uralvagonzavod is reached. This cooperation is in the field of service maintenance and repair of the armored equipment delivered to the Azerbaijani partners. Besides, favorable conditions for negotiation process between JSC Uralvagonzavod and the limited company "The Azerbaijani railways" concerning export of production of the Ural enterprise are created. As a result of the negotiations of March 2014, the contract for delivery of 2.9 thousand modern cars by JSC Uralvagonzavod to the Republic of Azerbaijan has been signed.

Kazakhstan, with which the Sverdlovsk region made the greatest number of agreements on the EAEU space, acts as the second example. So, the plan to the agreement about the partnership with the Karaganda region of Kazakhstan for 20142016 contains, among others, in the area of industrial production-organizing the partnership between the special economic zone of Karaganda region "Saryarka" and Sverdlovsk "Titanium valley”, as well as cooperation in agriculture. Such agreements contribute to the fact that Kazakhstan has the first place according to the international trade turnover among the partner countries of Sverdlovsk region from the CIS countries.

2. As for the institutionalization of countries' international economic partnership in the form of associations, which is manifested also at the level of the regions of the member countries, it is possible to mark out such new association, both chronologically and instrumentally, as BRICS group within which, the Strategy of economic partnership is accepted and the bank of development is created, and also the Platform for cooperation development in the field of electronic trading is created. By Russia, the Concept of participation in this association (passed 2013) is developed.

Concerning the level of intra-country region, in particular, the Sverdlovsk region, it can be mentioned that in the geographical structure of its export in 2013 in the majority of the items of machine-technical products, there prevails (as well as in 2012) the share of the developing countries of BRICS and SCO (one more new association, where a development bank will be also created), in opposition to the share of developed countries of EU and NAFTA (table 5).

Out of 10 commodities' positions, which were supplied in 2013 at least to one of the groups of countries considered, in 7 ways, the majority stays by the groups of developing partner countries of 
Table 5

Share of the BRICS and SCO, EU and NAFTA countries at the structure of export ${ }^{\star}$ of machines, equipment and transport facilities of Sverdlovsk region, 2013

\begin{tabular}{|l|c|c|}
\hline \multirow{2}{*}{\multicolumn{1}{|c|}{ Commodity position }} \\
& \multicolumn{2}{c|}{ Share of country groups at the structure of export, \% } \\
\cline { 2 - 3 } & BRICS and SCO $^{* * *}$ & EU and NAFTA \\
\hline Internal combustion engines & $\mathbf{1 8 , 1}$ & 0 \\
\hline Metal-cutting machines & $\mathbf{4 1 , 7}$ & 0 \\
\hline Ball and roll bearings & $\mathbf{3 0 , 0}$ & 5,4 \\
\hline Electrical motors and generators & $\mathbf{4 5 , 4}$ & 18,7 \\
\hline Electrical transformers and converters & $\mathbf{3 5 , 2}$ & 81,3 \\
\hline Receiving apparatus for tele- and video-communication & 0 & 48,6 \\
\hline Isolated wires, cables & 2,4 & 0 \\
\hline Light vehicles and other motor transport & $\mathbf{1 0 0}$ & 0 \\
\hline Tracks & $\mathbf{2 2 , 2}$ & 14,6 \\
\hline Components of motor transport vehicles & 0 & \\
\hline
\end{tabular}

* For calculation, the export expressed in physical terms is accounted.

** Only those commodity positions are accounted, which are exported at least to one of the country groups considered.

${ }^{* * *}$ Kazakhstan is not taken into account because of the functioning of the Customs union of EAEU.

Bolded numbers shows that the share of BRICS and SCO prevails.

Calculated on: International trade of Sverdlovsk region 2013: statistical bulletin. (2013). Territorial branch of Federal State Statistics Service on Sverdlovsk region. Yekaterinburg, 41. (25-27).

Russia. So, in the structure of the export of light vehicles and other motor transport in the countries of BRICS and SCO falls the whole export of the region, in the case of electrical motors and generators-almost $1 / 2$, in the case of metal-cutting machines $-2 / 5$, in the case of transformers and bearings $-1 / 3$ etc. - by the much lower, sometimes zero, shares of EU and NAFTA. That is the trade with the countries of BRICS and SCO in the higher extent corresponds to the vector on import substitution chosen in 2014. Thus, the organizing of these institutes of international economic partnership influences the development of the regional economy positively.

Other manifestations of the institutionalization of partnership within BRICS group, in particular, the institutionalization of scientific cooperation, also influence the regional economy positively. So, in 2015, the Memorandum of mutual understanding concerning science, technologies and innovations is made. In this sphere, the BRICS Network University is created. Now, the decision about entering into it from Russian side is made, along with capital higher education institutions, by 7 higher education institutions from other Russian regions, including the Ural Federal University (Sverdlovsk region). Within the group, it is planed: support of micro-, small- and medium-sized enterprises in technologies' and innovations' field, creation of innovative and technological clusters, zones of high technologies, scientific parks and incubators; development of youth exchanges for training in enterprises of the BRICS and SCO countries; forming the system of adopted towns; creation of integrated tele-medical systems in regions of the BRICS countries. Obviously, all these initiatives will further develop the regions' economies of the group's countries.

3. Such manifestation of IEA institutional provision as organizing and carrying out in a region the international events related to international cooperation in various economic branches (summits, exhibitions and fairs, visits of delegations), with the involvement of new network technologies of interaction, has the indirect postponed effect for the development of regional economy. Here, it is possible to mention the carrying out in a region the most relevant exhibitions of international scale (in the case of Sverdlovsk region - "Innoprom"). At the level of country's region, by such exhibitions and fairs, the summits, intergovernmental and other consultations, the following standard positive phenomena (reflecting the indirect effect) are observed:

- budgetary and private financial resources are invested into the development of infrastructure, in particular: constructing the buildings and roads, transport, organization of catering, business infrastructure;

- hotel economy of the region has been developed;

- local products have been advertised. Delegates and visitors of event consume them, take samples of local products "on test" and advertise them in their countries;

- large and strategic contracts on delivery of goods and cooperation has been made. So, German experience shows that the contracts made on in- 
ternational industrial fairs provide about onethird of export of their participants, or about $8 \%$ of their turnover (Andreeva E. L. Export promotion during structural transformations of national economy. PhD thesis in Economics. 1995);

- tourism industry has been developed, including the arrangement and advertizing of routes.

- consulting firms including international come to the region, which can consult further the local enterprises concerning carrying out the IEA;

- companies of the region have an opportunity to exchange experience with representatives of other countries.

Thus, this effect, often postponed, is expressed through providing an impulse (starting point) for the further development of regional economy.

Among events with the participation of the representatives of SCO and BRICS countries, which were carried out on the territory of the Sverdlovsk region, the most large-scale are the Meeting of Heads of SCO Countries' Governments (June 15, 2009) and the Summit of BRIC Group (June 16, 2009; at that time - without South Africa). Within preparation for the summits the following infrastructure was developed:

- Within transport infrastructure, the modern terminal complex at the airport was built. With the start of new terminals the passenger traffic was grown several times. The highway connecting the airport with the city was expanded. The airport was connected with the railroad station by train. The car fleet of the regional government and of road inspection was increased (the Business Quarter (Yekaterinburg). 15.6.2009).

- The impulse to development was received by congress activity. The first big project in this area was realized: the complex of information and technological systems for decision support (for congress activity) on 230 workplaces was equipped.

- The fire equipment for high-rise fire was purchased for the first time.

- In the hotel sphere, the opening of at least 5 hotels with more than 1000 rooms was planned 2009. 1.5 thousand of staff members of Yekaterinburg hotels were trained for dealing with guests. Business tourism received the impulse to development (Russian newspaper. 27.5.2009).

- In the sphere of construction and development of tourism industry for 2008-2009, 343 objects were repaired. The attention was paid to consideration of the city as a tourist product. (Business Quarter (Yekaterinburg). 15.6.2009).

- The contribution is made to the development of national cultural traditions and folk crafts.
During the event preparation, the overwhelming part of the costs was financed by business structures.

Also, the events in the Sverdlovsk region have been carried out related to the cooperation within the Eurasian integration. So, the Eurasian Economic Forum of Youth is carried out annually on the base of the Ural State Economic University. There participate the representatives of higher education institutions, companies, business associations. During 5 years, 6.5 thousand people from 60 countries participated in a forum. In the organizing of the forum, the Sverdlovsk region actively cooperates with Kazakhstan (eurasia-forum.ru). In 2013, the Youth Forum "Russia - Kazakhstan" within the 10th Forum of Interregional Cooperation of Two Countries took place in the region.

At present time, the international exhibition "Innoprom" is increasing its value and being carried out in Sverdlovsk region in 2016 for the 6th time. In 2015, it was visited by 52 thousand people. Today, over 600 industrial companies from 90 countries, including the leading state corporations, a number of the international exhibitors, participate in it. In 2015, China was the partner country of Russia to carrying out the exhibition, in 2016 it was India (according to the website innoprom.com). With China within "Innoprom-2016" devoted to the industrial network interaction, the III joint exhibition "Russian-Chinese Expo" collected 300 Russian and Chinese enterprises (according to the website russiachinaexpo.com).

The exhibition center "Yekaterinburg EXPO" was built and then expanded to carry out the most important international exhibitions. For the "Innoprom-2017", it is planned to build the congress hall of global scale with a capacity up to 7 thousand people. For such international event as the World Football Championship 2018, 4 hotels are planned to be build. Quantitatively, the development of hotel sphere is expressed through the fact, that the tourist flow to the Sverdlovsk region in 2015 achieved 2.5 million people. The additional revenue of hotels from "Innoprom-2016" is amounted to about 194 million of rubles, and the total direct (instant) the effect of guests' arrival to the exhibition for the region is amounted to about 1 billion of rubles (Newspaper of Sverdlovsk region. 11.7.2016). Indirect effect from "Innoprom-2015" can be expressed in the increase in a goods turnover of the region with China by almost 3 times in a year (according to Internet media "Moskovsky Komsomolets - the Urals. Sverdlovsk and Kurgan region". Retrieved from: http://eburg.mk.ru/articles/2016/07/11/sverdlovskiy-gubernator-rass- 
kazal-o-pryamom-i-prostom-effekte-ot-innoproma.html).

The investments, which have come to the region and the country directly after exhibitions and fairs and summits gave an impulse for the further development of Yekaterinburg and Sverdlovsk region, also due to further attraction of large foreign investments.

\section{Conclusion}

It is possible to draw a conclusion about the confirmation of the thesis pushed by the authors that the institutional factor of IEA is provided at the regional level by three manifestations: agreements of region about economic cooperation in various spheres with regional authorities of foreign countries; manifestation of institutionalization of countries' economic partnership at the level of region; organizing and carrying out in the region the international events related to international cooperation in various economy branches with the involvement of new network technologies of interaction. These manifestations act as one of the measurements of the offered three-dimensional methodology of the research of the influence of IEA institutional factor on the development of regional economy. The groups of the countries-international economic partners of region-developed countries-partners; countries-partners of CIS, including those of Eurasian economic union; other developing countries-partners (by BRICS group, SCO, etc.) are the second element of the methodology. The third measurement are the indicators of the regional economic development caused by institutional fac- tor-quantitative (increase of export, number of workplaces, inflow of investments) and qualitative (improvement of regional image, diversification of its economy).

The testing of the model offered in the example of the Sverdlovsk region of Russia shows the existence of all listed manifestations of IEA institutional component and the existence of the positive effect for them-mostly indirect and postponed in time, but representing an impulse for the further development of the region. The development of comprehensive economic integration with the target countries-international economic partners can change radically the direction of the flows of knowledge-intensive and high-technology goods and services, capital and technologies. The Sverdlovsk region, in particular, and Russia, in general, gets an opportunity to become a source of goods and services of high processing extent and investments. The purposeful accounting of institutional factor for Russia and its regions will promote:

- carrying out the modernization and diversification of economy;

- increase of a share of high-technological and knowledge-intensive products, including in export structure;

- development of the strategic infrastructure projects having the big integration importance and being the engine for growth of the regions of the Eurasian space;

- implementation of such most important project as the development of the Arctic;

- increase of region's status in international economic space.

\section{References}

1. Popov, E. \& Vlasov, M. (2015). Economic institutions of Russian academic science. Mediterranean Journal of Social Sciences, 6(3), 617-626.

2. Polterovich, V. M. (2013). Obshchiy institutsionalnyy analiz i proektirovanie reform [General social analysis and reform design]. Zhurnal novoy ekonomicheskoy assotsiatsii [Journal of the new economic association], 1(17), $185-188$.

3. North, D. C. (2010). Ponimanie protsessa ekonomicheskih izmeneniy [Understanding the process of economic changes]. Moscow: Higher School of Economics Publ., 256.

4. Francois, J. \& Manchin, M. (2013). Institutions, Infrastructure, and Trade. World Development, 46, $165-175$.

5. He, K. (2015). Contested regional orders and institutional balancing in the Asia Pacific. International Politics, 52(2), 208-222.

6. Kucik, J. (2012). The Domestic Politics of Institutional Design: Producer Preferences over Trade Agreement Rules. Economics and Politics, 24(2), 95-118.

7. Myslyakova, J. G. (2008). Institutsionalizaciya sotsialnoy otvetstvennosti biznesa: evolyutsionnyy aspekt [The institutionalization of the social business responsibility: evolutional aspect]. Zhurnal ekonomicheskoy teorii [Journal of economic theory], 3, 45-57.

8. Kuznetsova, G. V. (2014). Razvitie nauchno-issledovatelskoy deyatelnosti v mirovoy ekonomike [The development of research activities in the global economy]. Rossiyskiy vneshneekonomicheskiy vestnik [Russian foreign trade journal], 7 , 23-40.

9. Reimer, V. V. \& Kokuytseva, T. V. (2012). International rating innovative potential of Russia. Rossiiskoye predprinimatelstvo [Russian Journal of Entrepreneurship], 3, 4. 
10. Kapustina, L. M. \& Drevalev, A. A. (2014). Opportunities and threats for the Russian copper industry after the country's accession to the World trade organization. 7th Annual EuroMed Conference of the EuroMed-Academy-of-Business (18-19 Sept. 2014, Kristiansand, Norway). Future of entrepreneurship, 908-921.

11. Korobitsyn, B. \& Kuklin, A. \& Nikulina, N. (2015). Corrected gross domestic product to assess sustainability of Russia for the 2006-2013 period after taking into account depletion of natural resources, environmental pollution and human capital aspects. International Multidisciplinary Scientific GeoConference Surveying Geology and Mining Ecology Management, SGEM 15th, 165-172.

12. Golovina, A. S. \& Radkovskaya, E. V. (2010). Razrabotka sistemy analiza ekonomicheskoy statistiki dlya regionalnykh issledovanii [Working out of the system for the analysis of economic statistics for regional research]. Nauchnye trudy Volnogo ekonomicheskogo obshchestva Rossii [Scientific proceedings of the Free economic community of Russia], 143, 294-300.

13. Maslennikov, M. I. (2008). Puti narashchivaniya eksportnogo potentsiala i vneshneekonomicheskoy ekspansii Rossii $i$ regionov Urala [Ways of increasing the export potential and international economic expansion of Russia and Ural regions]. Ekaterinburg: Institute of economics of UB RAS Publ., 217.

14. Frolova, E. D. \& Frolova, E. A. (2014). Changes in industrial districts development in conditions of knowledge spillovers (Italian case). Ekonomika regiona [Economy of region], 3, 182-191.

15. Strovsky, L. E., Frolova, E. D. \& Strovsky, D. L. (2012). Osnovy vystavochno-yarmarochnoy deyatelnosti [Fundamentals of exhibition and fair activity]. Moscow: YuNITI-DANA Publ., 290.

16. Maltsev, A. \& Linetsky, A. (1997). Razvitie torgovo-ekonomicheskogo sotrudnichestva Sverdlovskoy oblasti s gosudarstvami-uchastnikami SNG [The development of the trade and economic cooperation of Sverdlovsk region with CIS states-member]. Vneshnyaya torgovlya [Foreign trade], 1-3, 35.

17. Sobolev, A. O. (2015). Zarubezhnyy opyt innovatsionnogo razvitiya staropromyshlennykh regionov i vozmozhnosti ego ispolzovaniya $\mathrm{v}$ Rossii [Foreign experience of innovative development of old industrial regions and possibilities of its use in Russia]. Voprosy upravleniya [Management issues], 1(13), 73-80.

18. Andreeva, E., Sapir, E., Karachev, I. \& Zherenkov, D. (2016). Export potential assessment of Russian pharmaceutical clusters. Proceedings of the 3rd SGEM international multidisciplinary scientific conference on social sciences and arts. Vol. 5. "Economics and tourism". Sofia. Book 2, 940, (245-252).

19. Andreeva, E. L., Zakharova, V. V. \& Ratner. A. V. (2014). Influence of international economic integration on socio-economic development of region. Ekonomika regiona [Economy of region], 3, 90-100.

20. Fityni, L. L. \& Abramova, I. O. (2012). Zakonomernosti formirovaniya i smeny modeley mirovogo ekonomicheskogo razvitiya [Regularities of forming and change of the models of world economic development]. Mirovaya ekonomika $i$ mezhdunarodnyye ekonomicheskie otnosheniya [World economy and international economic relations], 7, 3-15.

21. Surnina, N. M., Kovalyov, V. E. \& Gayterova, O. A. (2012). Aktualnyye voprosy vneshnetorgovogo sotrudnichestva na evraziiskom prostranstve [Topical issues of foreign cooperation in Eurasia]. Upravlenets [The Manager], 1-2, 66-71.

22. Duer, A., Baccini, L. \& Elsig, M. (2014). The design of international trade agreements: Introducing a new dataset. Review of International Organizations, 9(3), 353-375.

23. Keck, A. \& Schropp, S. (2008). Indisputably essential: The economics of dispute settlement institutions in trade agreements. Journal of World Trade, 42(5), 785-812.

\section{Authors}

Elena Leonidovna Andreeva - Doctor of Economics, Professor, Head of the Centre of Regional Comparative Research, Institute of Economics of the Ural Branch of RAS; Professor of Global Economic Department, Ural State University of Economics (29, Moskovskaya St., Ekaterinburg, 620014, Russian Federation; e-mail: elenandr@mail.ru).

Aleksandr Fyodorovich Linetsky - Doctor of Economics, Assistant Professor, Professor of Foreign Economic Activity Department, Ural State University of Economics; Leading Research Associate, Centre of Regional Comparative Research, Institute of Economics of the Ural Branch of RAS (62, 8 March St., Ekaterinburg, 620144, Russian Federation; e-mail: lin-af@ mail.ru).

Artem Vitalyevich Ratner- PhD in Economics, Research Associate, Centre of Regional Comparative Research, Institute of Economics of the Ural Branch of RAS (29, Moskovskaya St., Ekaterinburg, 620014, Russian Federation; e-mail: aratner@inbox.ru).

Darya Evgenyevna Kuznetsova - PhD Student, Institute of Economics of the Ural Branch of RAS (29, Moskovskaya St., Ekaterinburg, 620014, Russian Federation; e-mail: gubarenko.daria@gmail.com). 